JAMP: Jurnal Adminitrasi dan Manajemen Pendidikan

Volume 1 Nomor 4 Desember 2018, Hal : 388-399

Tersedia Online di http://journal2.um.ac.id/index.php/jamp/

ISSN 2615-8574 (online)

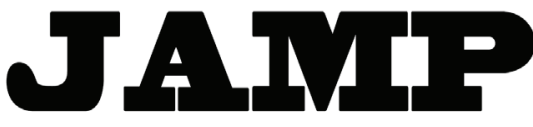

JURNAL ADMINISTRASI DAN MANAJEMEN PENDIDIKAN

\title{
ANALISIS KEBUTUHAN TENAGA ADMINISTRASI SEKOLAH PADA JENJANG SMA DAN SMK
}

\author{
Bayu Pramudya \\ Ibrahim Bafadal \\ Teguh Triwiyanto \\ bayupramudya@gmail.com \\ Universitas Negeri Malang, Jalan Semarang No.5 Malang
}

\begin{abstract}
This study aims to, (1) find out the number of shool administration staff at Senior and Vocational High School in District of Ngawi; (2) Knowing how high the school administration staff needs are based on the ratio of students for the next ten years; (3) Knowing how high the percentage of the needs of school administration staff at Senior and Vocational High School in District of Ngawi. This study uses a quantitative approach with a descriptive projective research design. Instrument in this study uses documentation method by recruiting data in the field. The data analysis technique used is a comparison of the ratio of school administration staff to the ratio of student, method of trend of parabolic, attrition, and moderate needs. The results of this study indicate: (1) The existence the count of administration staff at senior and vocational high school in Ngawi Regency in 2018-2027 (2) Needs for senior and vocational high school administration staff in Ngawi Regency is based on the ratio of students (3) Percentage of need for administration staff of senior and vocational high school at Ngawi District in 2018-2027
\end{abstract}

Keyword: needs analyst, school administration staff.

\begin{abstract}
Abstrak: Penelitian ini bertujuan untuk, (1) Mengetahui Jumlah Tenaga Administrasi Sekolah Sekolah Menengah Atas (SMA) dan Sekolah Menengah Kejuruan (SMK) Negeri di Kabupaten Ngawi; (2) Mengetahui seberapa tinggi kebutuhan TAS berdasarkan rasio peserta didik selama sepuluh tahun yang akan datang; (3) Mengetahui seberapa tinggi tingkat persentase kebutuhan tenaga administrasi sekolah SMA dan SMK Negeri di Kabupaten Ngawi. Penelitian ini menggunakan pendekatan kuantitatif dengan rancangan penelitian deskriptif proyektif. Instrumen dalam penelitian ini menggunakan metode dokumentasi dengan menyalin data yang ada di lapangan. Teknik analisis data yang digunakan adalah perbandingan rasio tenaga adinistrasi sekolah dengan rasio peserta didik, metode trend parabola, atrisi, dan kebutuhan moderat. Hasil penelitian ini menunjukan (1) Keberadaan jumlah tenaga administrasi sekolah SMA dan SMK Negeri di Kabupaten Ngawi pada Tahun 2018-2027; (2) Kebutuhan tenaga administrasi sekolah SMA dan SMK Negeri di Kabupaten Ngawi berdasarkan rasio peserta didik; (3) Persentase kebutuhan tenaga administrasi sekolah SMA dan SMK Negeri di Kabupaten Ngawi Tahun 2018-2027
\end{abstract}

Kata kunci: analisis kebutuhan, tenaga administrasi sekolah

Keberhasilan pelaksanaan pendidikan ditentukan oleh beberapa faktor salah satunya yaitu tenaga kependidikan, atau tenaga administrasi sekolah. tenaga kependidikan sangat dibutuhkan untuk menunjang penyelenggaraan pendidikan, dengan adanya tenaga kependidikan tersebut penyelenggaraan pendidikan dapat berjalan lancar karena selain guru sebagai pengajar dibutuhkan petugas yang membantu dalam pelaksanaan proses pendidikan selain pembelajaran. Tenaga Administrasi Sekolah (TAS) merupakan 
salah satu jenis tenaga kependidikan yaitu tenaga di luar tenaga pengajar yang tugasnya mempersiapkan dan mempelancar pelaksanaan pendidikan baik secara teknis maupun manajerial. Supriadi dalam Hidayat (2014) menyatakan "tenaga kependidikan bertugas melaksanakan administrasi, pengelolaan, pengembangan, pengawasan, dan pelayanan teknis untuk menunjang proses pendidikan pada satuan pendidikan". Tenaga Administrasi Sekolah dalam hal ini menempati peran penting sebagai tenaga kependidikan dengan tugasnya yang bukan hanya sekedar membantu sekolah dalam urusan administrasi melainkan meliputi beberapa kegiatan penting dalam pengembangan kualitas sekolah seperti pengelolaan, pengembangan, pengawasan dan pelayanan teknis. Tenaga Administrasi Sekolah ini juga bertugas sebagai pendukung berjalannya proses pendidikan di sekolah melalui layanan administratif guna terselenggaranya proses pendidikan yang efektif dan efisien di sekolah.

Perencanaan yang baik dalam proses pendidikan sangat dibutuhkan agar sumber daya manusia yang ada sesuai dengan kompetensi yang dimilikinya. Langkah awal prosedur pelaksanaan pendidikan yaitu analisis kebutuhan.yang di dalamnya terdapat komponen-komponen pendidikan. Analisis kebutuhan berdasarkan Peraturan Menteri Pendayagunaan Aparatur Negara No 75 Tahun 2004 tentang Pedoman perhitungan Kebutuhan Pegawai dalam Rangka Penyusunan Formasi Pegawai Negeri Sipil menyatakan "analisis kebutuhan pegawai adalah proses yang dilakukan secara logik, teratur, dan berkesinambungan untuk mengetahui jumlah dan kualitas pegawai yang diperlukan".

Analisis kebutuhan menurut Anderson, dkk dalam Arikunto \& Safruddin (2010:71) diartikan sebagai "suatu proses yang dilakukan oleh seseorang untuk mengidentifikasi kebutuhan sekaligus menentukan prioritas diantaranya". Selain itu menurut Kaufman dan Fenwick dalam Sonhadji \& Huda (2014:40) mendifinisikan analisis kebutuhan merupakan "suatu pengukuran kesenjangan antara apa yang terjadi dengan apa yang diinginkan". Berdasarkan pendapat tersebut analisis kebutuhan diartikan sebagai suatu kondisi yang memperlihatkan adanya kesenjangan antara keadaan nyata (yang ada) dengan kondisi yang diharapkan.

Kesesuaian kualifikasi tenaga kependidikan juga harus dipertimbangkan dalam perencanaan pendidikan. Kepentingan itu diperlukan manajemen yang profesional didukung penyelenggaraan administrasi sekolah yang profesional pula, yang ditangani oleh tenaga administrasi yang kompeten dalam bidangnya. Tenaga Administrasi Sekolah menurut Priadi (2012) adalah tenaga kependidikan yang bertugas memberikan dukungan layanan administrasi guna terselenggaranya proses pendidikan di sekolah. Bersama-sama dengan komponen yang lain, unit kesekretariatan beraktivitas dalam rangka mendukung tercapainya tujuan sekolah. Selain itu tenaga administrasi sekolah menurut Hidayat \& Nurhikmahyanti (2014) adalah tenaga kependidikan yang bertugas memberikan dukungan layanan administrasi seluruh warga sekolah dalam hal teknis administrasi, kearsipan dan persuratan. Tenaga administrasi sekolah/madrasah selain harus memenuhi standar kualifikasi juga diperlukan sebuah kompetensi untuk mengimbangi kualifikasi yang telah dimilikinya. Menurut Junaidi dalam Syarifuddin (2011) "kompetensi adalah kemampuan melaksanakan tugas yang diperoleh melalui pendidikan dan atau latihan".

Kompetensi Tenaga Administrasi Sekolah adalah kemampuan yang diperoleh tenaga administrasi sekolah melalui pendidikan pada suatu pendidikan. Kompetensi tenaga administrasi sekolah disini sebagai kemampuan untuk melaksanakan tugas, peran, dan kemampuan mengintegrasikan pengetahuan yang didasarkan pada pengalaman dan pembelajaran yang dilakukan dalam pelaksanaan pekerjaannya yang dituntut dalam kecakapan teknis operasional atau teknis administrastif di sekolah. Guna mengetahui jumlah kebutuhan TAS dalam rentang waktu tertentu maka di perlukan proyeksi. Proyeksi merupakan salah satu langkah lanjutan dalam proses perencanaan pendidikan, setelah diperoleh data dana berbagai informasi yang dibutuhkan, perencana akan melakukan proyeksi untuk mengetahui dan memprediksi halhal yang akan terjadi di masa yang akan datang. Cara memproyeksikan pendidikan metode trend dapat digunakan untuk menghitung proyeksi kebutuhan tenaga administrasi dengan cara mengumpulkan data yang ada. Penggunaan metode trend dalam penelitian ini untuk mengetahui perkiraan atau peramalan jumlah tenaga administrasi dalam rentang waktu tertentu. 


\section{METODE}

Penelitian ini menggunakan pendekatan deskriptif-proyektif berdasarkan data kuantitatif yang diperoleh dari hasil data empirik. Jenis penelitian ini dikatakan sebagai penelitian pridiktif, karena berupaya membuat proyeksi kebutuhan tenaga admnistrasi sekolah di SMA dan SMK Negeri SeKabupaten Ngawi. Penelitian kuantitatif dimaksudkan untuk mendeskripsikan suatu fenomena sebagaimana adanya pada waktu penelitian dilakukan (Wiyono, 2007: 28). Setyadin (2005: 11) mengemukakan bahwa, "penelitian deskriptif bertujuan untuk menggambarkan secara tepat karakteristik suatu gejala frekuensi dan distribusinya".

Data yang digunakan pada penelitian ini yaitu data kepegawaian SMA dan SMK Negeri di Kabupaten Ngawi dengan jumlah keseluruhan ada 21 Sekolah. Teknik analisis dalam penelitian ini menggunakan metode Ratio Trend, Atrisi, dan Tedensi Sentral. Menurut Yuliawati (2014: 1) metode ratio trend adalah "metode yang digunkan untuk memperkirakan permintaan tenaga kerja dengan mengetahui beban kerja, dan kapasitas sekolah pada periode perencanaan tertentu. Metode ratio trend dapat digunakan dalam keadaan aktivitas pekerjaan yang hanya mengalami perubahan sedikit saja". Proyeksi kebutuhan TAS memerlukan data rasio perbandingan antara TAS dan peserta didik. Rasio perbandingan tersebut didapatkan dari perhitungan dengan didasarkan pada rombongan belajar (rombel).

Setelah diketahui kebutuhan TAS di setiap sekolah maka dapat diketahui pula rasio perbandingan antara TAS dan peserta didik pada tahun tersebut. Penelitian ini menggunakan metode time series tepatnya motede trend parabola, hal ini dikarenakan dalam penelitian ini menggunakan periode waktu/ tahun untuk melakukan prediksi dalam jangka panjang mengenai kebutuhan TAS pada SMA dan SMK Negeri di Kabupaten Ngawi. Penggunaan rumus atrisi yaitu untuk menentukan kebutuhan jumlah tenaga kerja berdasarkan jumlah tenaga kerja yang keluar karena alasan umur, kesehatan, kematian, dll.

\section{HASIL}

Berdasarkan hasil penelitian analisis kebutuhan TAS SMA dan SMK Negeri di UPT Dinas Pendidikan Kabupaten Ngawi, maka hasil penelitian diperoleh deskripsi sebagai berikut.

\section{Analisis Proyeksi Jumlah TAS Tahun 2018-2027}

Berdasarkan Tabel 1 dapat diketahui bahwa selama 2018 sampai dengan 2022 tidak terjadi kenaikan jumlah pegawai. Pada tahun-tahun selanjutnya jumlah pegawai mengalami kenaikan secara konstan yaitu sejumlah 1 pegawai di tiap tahunnya. Tahun 2022 ke tahun 2023 jumlah pegawai mengalami kenaikan sejumlah 1,81\%. Tahun 2023 ke tahun 2024 jumlah pegawai mengalami kenaikan sejumlah 1,79\%. Tahun 2024 ke tahun 2025 jumlah pegawai mengalami kenaikan sejumlah 1,76\%. Tahun 2025 ke tahun 2026 jumlah pegawai mengalami kenaikan sejumlah 1,73\%. Tahun 2026 ke tahun 2027 jumlah pegawai mengalami kenaikan sejumlah $1,70 \%$.

Tabel 1 Poyeksi TAS SMA Negeri Tahun 2018-2027

\begin{tabular}{cc}
\hline Tahun & TAS \\
\hline 2018 & 55 orang \\
2019 & 55 orang \\
2020 & 55 orang \\
2021 & 55 orang \\
2022 & 55 orang \\
2023 & 56 orang \\
2024 & 57 orang \\
2025 & 58 orang \\
2026 & 59 orang \\
2027 & 60 orang \\
\hline
\end{tabular}


Berdasarkan Tabel 1 dari tiap tahunnya jumlah TAS mengalami kenaikan secara konstan. Pada tahun 2018 jumlah TAS di proyeksikan sejumlah 109 orang. Tahun 2019 jumlah TAS mengalami kenaikan sebanyak 9 orang atau 8,54\%. Tahun 2020 jumlah TAS mengalami kenaikan sebanyak 10 orang atau 8,82\%. Tahun 2021 jumlah TAS mengalami kenaikan sebanyak 12 orang atau 8,98\%. Tahun 2022 jumlah TAS mengalami kenaikan sebanyak 13 orang atau 9,05\%. Tahun 2023 jumlah TAS mengalami kenaikan sebanyak 14 orang atau $9,03 \%$. Tahun 2024 jumlah TAS mengalami kenaikan sebanyak 15 orang atau 8,96\%. Tahun 2025 jumlah TAS mengalami kenaikan sebanyak 16 orang atau 8,85\%. Tahun 2026 jumlah TAS mengalami kenaikan sebanyak 17 orang atau 8,70\%. Tahun 2027 jumlah TAS mengalami kenaikan sebanyak 18 orang atau 8,53\%.

Tabel 2 Proyeksi TAS SMK Negeri Tahun 2018-2027

\begin{tabular}{cc}
\hline Tahun & TAS \\
\hline 2018 & 109 Orang \\
2019 & 119 Orang \\
2020 & 129 Orang \\
2021 & 141 Orang \\
2022 & 153 Orang \\
2023 & 167 Orang \\
2024 & 182 Orang \\
2025 & 198 Orang \\
2026 & 215 Orang \\
2027 & 234 Orang \\
\hline
\end{tabular}

Analisis Proyeksi Jumlah TAS Berdasarkan Rasio Peserta Didik

Tabel 3 Proyeksi TAS SMA Negeri Berdasarkan Rasio Peserta Didik

\begin{tabular}{ccccc}
\hline Tahun & $\begin{array}{c}\text { Jumlah Peserta } \\
\text { Didik }\end{array}$ & TAS Ideal & TAS Yang Ada & Kebutuhan TAS \\
\hline 2018 & 7473 & 108 & 55 & 81 \\
2019 & 7865 & 113 & 55 & 84 \\
2020 & 8301 & 120 & 55 & 87 \\
2021 & 8782 & 126 & 55 & 91 \\
2022 & 9306 & 134 & 55 & 95 \\
2023 & 9874 & 142 & 56 & 99 \\
2024 & 10486 & 151 & 57 & 104 \\
2025 & 11143 & 160 & 58 & 109 \\
2026 & 11843 & 170 & 59 & 115 \\
2027 & 12587 & 181 & 60 & 121 \\
\hline
\end{tabular}

Berdasarkan Tabel 3 dapat diketahui jumlah kebutuhan TAS SMA Negeri Kabupaten Ngawi mengalami kenaikan di tiap tahunnya. Tahun 2018 menunjukan jumlah peserta didik 7473 orang, dari jumlah peserta yang ada rasio ideal TAS yang harus ada sebanyak 108 orang. Dilihat dari TAS yang diperkirakan di tahun tersebut jumlah TAS yang ada sebanyak 55 orang, kebutuhan TAS yang harus dipenuhi sebanyak 81 orang, jadi TAS pada tahun 2018 memiliki kekurangan sebanyak 26 orang. Tahun 2019 menunjukan jumlah peserta didik menjadi 7865 orang, dari jumlah peserta yang ada rasio ideal TAS yang harus ada sebanyak 113 orang. Dilihat dari TAS yang diperkirakan di tahun tersebut jumlah TAS yang ada sebanyak 55 orang, kebutuhan TAS yang harus dipenuhi sebanyak 84 orang, jadi TAS pada tahun 2019 memiliki 
kekurangan sebanyak 29 orang. Tahun 2020 menunjukan jumlah peserta didik menjadi 8301 orang, dari jumlah peserta yang ada rasio ideal TAS yang harus ada sebanyak 120 orang. Dilihat dari TAS yang diperkirakan di tahun tersebut jumlah TAS yang ada sebanyak 55 orang, kebutuhan TAS yang harus dipenuhi sebanyak 87 orang, jadi TAS pada tahun 2020 memiliki kekurangan sebanyak 32 orang. Tahun 2021 menunjukan jumlah peserta didik sebanyak 8782 orang, dari jumlah peserta yang ada rasio ideal TAS yang harus ada sebanyak 126 orang. Dilihat dari TAS yang diperkirakan di tahun tersebut jumlah TAS yang ada sebanyak 55 orang, kebutuhan TAS yang harus dipenuhi sebanyak 91 orang, jadi TAS pada tahun 2021 memiliki kekurangan sebanyak 36 orang. Tahun 2022 menunjukan jumlah peserta didik sebanyak 9306, dari jumlah peserta yang ada rasio ideal TAS yang harus ada sebanyak 134 orang. Dilihat dari TAS yang diperkirakan di tahun tersebut jumlah TAS yang ada sebanyak 55 orang, kebutuhan TAS yang harus dipenuhi sebanyak 95 orang, jadi TAS pada tahun 2022 memiliki kekurangan sebanyak 40 orang.

Tahun 2023 menunjukan jumlah peserta didik sebanyak 9874 orang, dari jumlah peserta yang ada rasio ideal TAS yang harus ada sebanyak 142 orang. Dilihat dari TAS yang diperkirakan di tahun tersebut jumlah TAS yang ada sebanyak 56 orang, kebutuhan TAS yang harus dipenuhi sebanyak 99 orang, jadi TAS pada tahun 2023 memiliki kekurangan sebanyak 43 orang. Tahun 2024 menunjukan jumlah peserta didik sebanyak 10486 orang, dari jumlah peserta yang ada rasio ideal TAS yang harus ada sebanyak 151 orang. Dilihat dari TAS yang diperkirakan di tahun tersebut jumlah TAS yang ada sebanyak 57 orang, kebutuhan TAS yang harus dipenuhi sebanyak 104 orang, jadi TAS pada tahun 2024 memiliki kekurangan sebanyak 47 orang. Tahun 2025 menunjukan jumlah peserta didik sebanyak 11143 orang, dari jumlah peserta yang ada rasio ideal TAS yang harus ada sebanyak 160 orang. Dilihat dari TAS yang diperkirakan di tahun tersebut jumlah TAS yang ada sebanyak 58 orang, kebutuhan TAS yang harus dipenuhi sebanyak 109 orang, jadi TAS pada tahun 2025 memiliki kekurangan sebanyak 51 orang. Tahun 2026 menunjukan jumlah peserta didik sebanyak 11843 orang, dari jumlah peserta yang ada rasio ideal TAS yang harus ada sebanyak 170 orang. Dilihat dari TAS yang diperkirakan di tahun tersebut jumlah TAS yang ada sebanyak 59 orang, kebutuhan TAS yang harus dipenuhi sebanyak 115 orang, jadi TAS pada tahun 2026 memiliki kekurangan sebanyak 56 orang. Tahun 2027 menunjukan jumlah peserta didik sebanyak 12587 orang, dari jumlah peserta yang ada rasio ideal TAS yang harus ada sebanyak 181 orang. Dilihat dari TAS yang diperkirakan di tahun tersebut jumlah TAS yang ada sebanyak 60 orang, kebutuhan TAS yang harus dipenuhi sebanyak 121 orang, jadi TAS pada tahun 2027 memiliki kekurangan sebanyak 61 orang.

Tabel 4 Proyeksi TAS SMK Negeri Berdasarkan Rasio Peserta Didik

\begin{tabular}{ccccc}
\hline Tahun & $\begin{array}{c}\text { Jumlah Peserta } \\
\text { Didik }\end{array}$ & TAS Ideal & TAS Yang Ada & Kebutuhan TAS \\
\hline 2018 & 12630 & 176 & 109 & 143 \\
2019 & 14036 & 196 & 119 & 157 \\
2020 & 15551 & 217 & 129 & 173 \\
2021 & 17176 & 240 & 141 & 190 \\
2022 & 18909 & 264 & 153 & 208 \\
2023 & 20751 & 289 & 167 & 228 \\
2024 & 22703 & 316 & 182 & 249 \\
2025 & 24703 & 345 & 198 & 271 \\
2026 & 26933 & 375 & 215 & 295 \\
2027 & 29212 & 407 & 234 & 320 \\
\hline
\end{tabular}


Berdasarkan Tabel 4 dapat diketahui bahwa jumlah kebutuhan TAS SMK negeri Kabupaten Ngawi mengalami kenaikan. Tahun 2018 menunjukan jumlah peserta didik sebesar 12630 orang, dari jumlah peserta yang ada rasio ideal TAS yang harus ada sebanyak 176 orang. Dilihat dari TAS yang diperkirakan di tahun tersebut jumlah TAS yang ada sebanyak 109 orang, kebutuhan TAS yang harus dipenuhi sebanyak 143 orang, jadi TAS pada tahun 2018 memiliki kekurangan sebanyak 34 orang. Tahun 2019 menunjukan jumlah peserta didik sebesar 14036 orang, dari jumlah peserta yang ada rasio ideal TAS yang harus ada sebanyak 196 orang. Dilihat dari TAS yang diperkirakan di tahun tersebut jumlah TAS yang ada sebanyak 119 orang, kebutuhan TAS yang harus dipenuhi sebanyak 157 orang, jadi TAS pada tahun 2019 memiliki kekurangan sebanyak 38 orang. Tahun 2020 menunjukan jumlah peserta didik sebesar 15551 orang, dari jumlah peserta yang ada rasio ideal TAS yang harus ada sebanyak 217 orang. Dilihat dari TAS yang diperkirakan di tahun tersebut jumlah TAS yang ada sebanyak 129 orang, kebutuhan TAS yang harus dipenuhi sebanyak 173 orang, jadi TAS pada tahun 2020 memiliki kekurangan sebanyak 44 orang. Tahun 2021 menunjukan jumlah peserta didik sebesar 17176 orang, dari jumlah peserta yang ada rasio ideal TAS yang harus ada sebanyak 240 orang. Dilihat dari TAS yang diperkirakan di tahun tersebut jumlah TAS yang ada sebanyak 141 orang, kebutuhan TAS yang harus dipenuhi sebanyak 190 orang, jadi TAS pada tahun 2021 memiliki kekurangan sebanyak 49 orang. Tahun 2022 menunjukan jumlah peserta didik sebesar 18909 orang, dari jumlah peserta yang ada rasio ideal TAS yang harus ada sebanyak 264 orang. Dilihat dari TAS yang diperkirakan di tahun tersebut jumlah TAS yang ada sebanyak 153 orang, kebutuhan TAS yang harus dipenuhi sebanyak 208 orang, jadi TAS pada tahun 2022 memiliki kekurangan sebanyak 55 orang.

Tahun 2023 menunjukan jumlah peserta didik sebesar 20751 orang, dari jumlah peserta yang ada rasio ideal TAS yang harus ada sebanyak 289 orang. Dilihat dari TAS yang diperkirakan di tahun tersebut jumlah TAS yang ada sebanyak 167 orang, kebutuhan TAS yang harus dipenuhi sebanyak 228 orang, jadi TAS pada tahun 2023 memiliki kekurangan sebanyak 61 orang. Tahun 2024 menunjukan jumlah peserta didik sebesar 22703 orang, dari jumlah peserta yang ada rasio ideal TAS yang harus ada sebanyak 316 orang. Dilihat dari TAS yang diperkirakan di tahun tersebut jumlah TAS yang ada sebanyak 182 orang, kebutuhan TAS yang harus dipenuhi sebanyak 249 orang, jadi TAS pada tahun 2024 memiliki kekurangan sebanyak 67 orang. Tahun 2025 menunjukan jumlah peserta didik sebesar 24763 orang, dari jumlah peserta yang ada rasio ideal TAS yang harus ada sebanyak 345 orang. Dilihat dari TAS yang diperkirakan di tahun tersebut jumlah TAS yang ada sebanyak 198 orang, kebutuhan TAS yang harus dipenuhi sebanyak 272 orang, jadi TAS pada tahun 2025 memiliki kekurangan sebanyak 74 orang. Tahun 2026 menunjukan jumlah peserta didik sebesar 26933 orang, dari jumlah peserta yang ada rasio ideal TAS yang harus ada sebanyak 375 orang. Dilihat dari TAS yang diperkirakan di tahun tersebut jumlah TAS yang ada sebanyak 215 orang, kebutuhan TAS yang harus dipenuhi sebanyak 295 orang, jadi TAS pada tahun 2026 memiliki kekurangan sebanyak 80 orang. Tahun 2027 menunjukan peserta didik sebesar 29212 orang, dari jumlah peserta yang ada rasio ideal TAS yang harus ada sebanyak 407 orang. Dilihat dari TAS yang diperkirakan di tahun tersebut jumlah TAS yang ada sebanyak 234 orang, kebutuhan TAS yang harus dipenuhi sebanyak 320 orang, jadi TAS pada tahun 2027 memiliki kekurangan sebanyak 86 orang. 


\section{Analisis Tingkat Presentase Kebutuhan TAS Tahun 2018-2027}

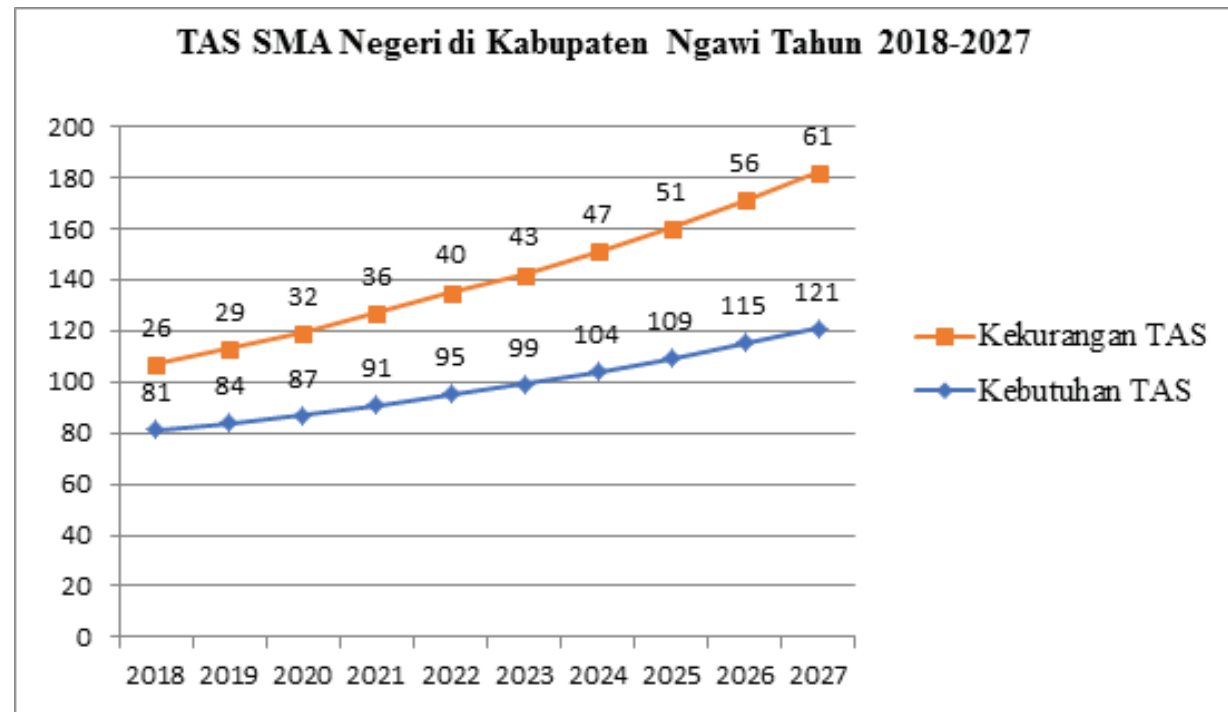

Gambar 1. Tingkat Kebutuhan TAS SMA Negeri di Kabupaten Ngawi Tahun 2018-2027

Berdasarkan Gambar 1. persentase kebutuhan TAS SMA Negeri di Kabupaten Ngawi pada tahun 2018 sebesar 32,10\%. Tahun 2019 persentase kebutuhan TAS SMA Negeri di Kabupaten Ngawi sebesar 34,52\%, tahun 2020 persentase kebutuhan TAS SMA Negeri di Kabupaten Ngawi sebesar 36,78\%. Tahun 2021 persentase kebutuhan TAS SMA Negeri di Kabupaten Ngawi sebesar 39,56\%. Tahun 2022 persentase kebutuhan TAS SMA Negeri di Kabupaten Ngawi sebesar 42,11\%. Tahun 2023 persentase kebutuhan TAS SMA Negeri di Kabupaten Ngawi sebesar 43,43\%. Tahun 2024 persentase kebutuhan TAS SMA Negeri di Kabupaten Ngawi sebesar 45,19\%. Tahun 2025 persentase kebutuhan TAS SMA Negeri di Kabupaten Ngawi sebesar 46,79\%. Tahun 2026 persentase kebutuhan TAS SMA Negeri di Kabupaten Ngawi sebesar 48,70\%. Tahun 2027 persentase kebutuhan TAS SMA Negeri di Kabupaten Ngawi sebesar 50,41\%.

TAS SMK Negeri di Kabupaten Ngawi Tahun 2018-2027

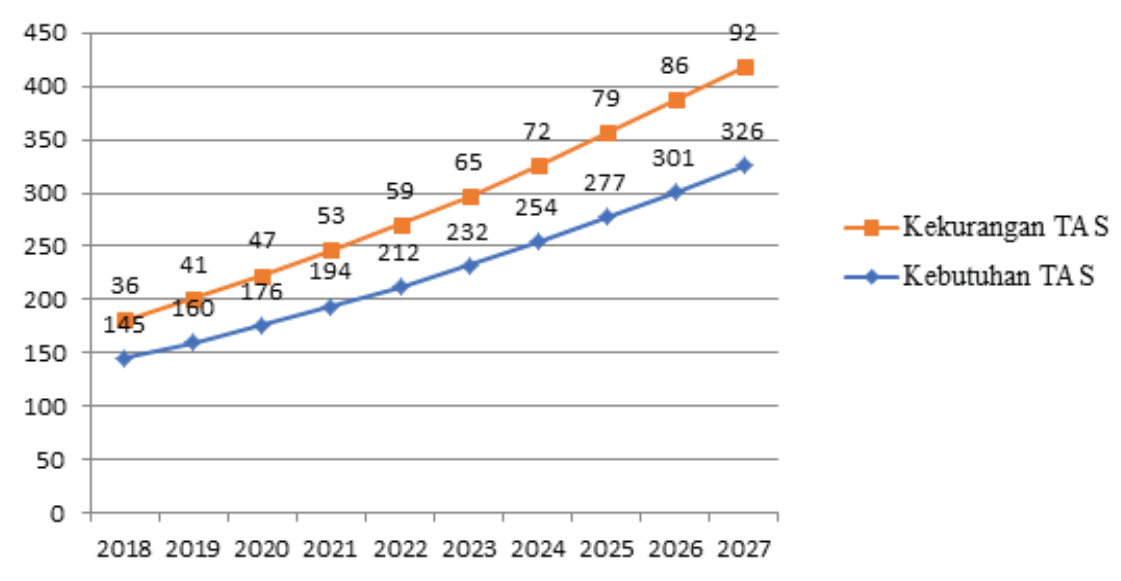

Gambar 4.6. Tingkat Kebutuhan TAS SMK Negeri di Kabupaten Ngawi Tahun 2018-2027

Berdasarkan Gambar 4.6. persentase kebutuhan TAS SMK Negeri di Kabupaten Ngawi pada tahun 2018 sebesar 23,78\%. Tahun 2019 persentase kebutuhan TAS SMK Negeri di Kabupaten Ngawi sebesar 24,20\%. Tahun 2020 persentase kebutuhan TAS SMK Negeri di 
Kabupaten Ngawi sebesar 25,43 \%. Tahun 2021 persentase kebutuhan TAS SMK Negeri di Kabupaten Ngawi sebesar 25,79\%. Tahun 2022 persentase kebutuhan TAS SMK Negeri di Kabupaten Ngawi sebesar 26,44\%. Tahun 2023 persentase kebutuhan TAS SMK Negeri di Kabupaten Ngawi sebesar 26,75\%. Tahun 2024 persentase kebutuhan TAS SMK Negeri di Kabupaten Ngawi sebesar 26,91\%. Tahun 2025 persentase kebutuhan TAS SMK Negeri di Kabupaten Ngawi sebesar 27,21\%. Tahun 2026 persentase kebutuhan TAS SMK Negeri di Kabupaten Ngawi sebesar 27,2\%. Tahun 2027 persentase kebutuhan TAS SMK Negeri di Kabupaten Ngawi sebesar 26,88 \%.

\section{PEMBAHASAN}

\section{Keberadaan TAS SMA dan SMK Negeri Tahun 2018-2027}

Tenaga Administrasi Sekolah menurut Priadi (2012) adalah "tenaga kependidikan yang bertugas memberikan dukungan layanan administrasi guna terselenggaranya proses pendidikan di sekolah". Sesuai dengan pendapat diatas TAS merupakan salah satu faktor penting dalam pelayanan proses pendidikan di sekolah. Pelayanan proses pendidikan dapat optimal apabila jumlah peserta didik yang ada di sekolah sebanding dengan jumlah TAS yang ada di sekolah, hal ini dikeranakan TAS berperan penting dalam pelayanan peserta didik di sekolah. Sesuai dengan Peraturan Menteri Pendidikan Nasional Nomor 24 Tahun 2008 tentang Standar Tenaga Administrasi Sekolah/Madrasah (TAS/M), jabatan TAS yaitu meliputi kepala administrasi sekolah, pelaksana urusan administrasi keuangan, pelaksana urusan administrasi kepegawaian, pelaksan urusan administrasi sarana dan prasarana, pelaksana urusan administrasi humas, pelaksana urusan administrasi persuratan dan pengarsipan, pelaksana urusan administrasi kesiswaan, pelaksana urusan administrasi kurikulum, dan petugas layanan khusus.

Proyeksi kebutuhan TAS dapat dilakukan setelah proses peramalan kebutuhan. Proyeksi merupakan tahap lanjutan dari proses peramalan dimana informasi yang telah terkumpul digunakan dalam proses proyeksi. Menurut Matin (2013: 101) proyeksi merupakan "suatu aktivitas memperkirakan suatu kondisi di masa depan berdasarkan data dan informasi di masa lampau dan masa kini". Sesuai dengan hal tersebut proyeksi TAS yang ada di SMA dan SMK Negeri di Kabupaten Ngawi memerlukan data jumlah TAS di masa lampau dan masa kini yang diperoleh melalui proses peramalan. Sesuai dengan teori yang ada tentang metode proyeksi, penelitian ini menggunakaan teknik analisis trend parabola dan atrisi. Penggunaan rumus perhitungan dengan trend parabola untuk memproyeksikan kebutuhan TAS SMA dan SMK Negeri di Kabupaten Ngawi dirasa sesuai, hal ini dikarenakan perhitungan dengan trend parabola diperlukan data masa lampau sebagai acuan melakukan proyeksi kebutuhan TAS. Atrisi merupakan metode atau teknik yang digunakan untuk menentukan kebutuhan jumlah tenaga kerja berdasarkan jumlah tenaga yang keluar karena alasan umur, kesehatan, kematian, dan lain-lain (Yuliawati, 2014: 1).

Atrisi dalam penelitian proyeksi kebutuhan TAS di SMA dan SMK Negeri di Kabupaten Ngawi yaitu pemberhentian karena pensiun, mutasi, dan kematian. Angka pensiun pegawai didapatkan dari data kepegawaian yang memaparkan tentang tanggal lahir pegawai, sedangkan mutasi dan kematian didapatkan dari penelitian dengan diperoleh data mutasi pegawai sepuluh tahun yang lalu kemudian data terssebut diproyeksikan untuk mengetahui data mutasi selama sepuluh tahun yang akan datang. Prosedur perhitungan proyeksi kebutuhan TAS SMA dan SMK Negeri di Kabupaten Ngawi selama sepuluh tahun mendatang sudah sesuai dengan prosedur yang ada, dengan cara menghitung proyeksi dengan rumus trend parabola yang digabung dengan rumus rombel serta ditambah rumus atrisi. Berdasarkan perhitungan proyeksi dengan menggunakan trend parabola dan atrisi dengan menggunakan data masa lampau jumlah TAS SMA negeri kabupaten Ngawi diperoleh hasil rata-rata mengalami kenaikan. Pada tahun 2018 hingga tahun 2022 jumlah TAS yang ada sebanyak 55 orang, tahun 2023 sebanyak 56 orang, 2024 sebanyak 57 orang, tahun 2025 sebanyak 58 orang, tahun 2026 sebanyak 59 orang, dan tahun 2027 sebanyak 60 orang. Sedangkan jumlah TAS SMK Negeri Kabupaten Ngawi diperoleh hasil dalam setiap tahunnya mengalami kenaikan. Pada tahun 2018 sebayak 109 orang, tahun 2019 sebanyak 119 orang, tahun 2020 sebanyak 129 orang, tahun 2021 sebanyak 141 orang, tahun 2022 sebanyak 153, tahun 2023 
sebanyak 167 orang, tahun 2024 sebanyak 182, tahun 2025 sebanyak 198 orang, tahun 2026 sebanyak 215 orang, dan tahun 2027 sebanyak 234 orang.

\section{Kebutuhan TAS SMA dan SMK Negeri Berdasarkan Rasio Peserta Didik Tahun 2018- 2027}

Berdasarkan analisis data yang telah dilakukan hasil kebutuhan TAS pada SMA dan SMK Negeri Kabupaten Ngawi mengalami kekurangan jumlah TAS. Rasio jumlah TAS dengan jumlah peserta didik adalah perbandingan jumlah TAS dengan jumlah peserta didik yang ada, agar TAS dapat melakukan pekerjaan secara optimal. Menurut Sonhadji dan Huda (2014:40) mendifinisikan analisis kebutuhan merupakan suatu pengukuran kesenjangan antara apa yang terjadi dengan apa yang diinginkan. Sesuai dengan pendapat diatas, kebutuhan TAS SMA dan SMK Negeri Kabupaten Ngawi diperoleh dari hasil analisis jumlah TAS yang sekarang ada di lapangan dengan beban kerja dalam pelayanan TAS terhadap peserta didik.

Kebutuhan pegawai berdasarkan peserta didik dihitung dengan menambahkan jumlah TAS yang ada dengan menambahkan selisih antara TAS dengan kebutuhan ideal TAS yang dibagi dua. Kebutuhan ideal didapatkan dari hasil membagi jumlah peserta didik sesuai dengan ideal peserta didik tiap rombel dan di bagi dua serta ditambah satu. Berdasarkan perhitungan tersebut, maka diperoleh kebutuhan moderat TAS pada SMA dan SMK Negeri di Kabupaten Ngawi. Perhitungan kebutuhan moderat ini yang nantinya menjadi kebutuhan TAS SMA dan SMK Negeri Kabupaten Ngawi yang harus ada, kebutuhan moderat ini dilakukan karena pemerintah tidak mungkin dapat memenuhi kebutuhan ideal TAS yang harus ada di tiap sekolah.

Perhitungan proyeksi kebutuhan TAS SMA Negeri di Kabupaten Ngawi berdasarkan rasio peserta didik diperoleh data TAS ideal yang harus ada. Berdasarkan perkembangan peserta didik yang ada diperoleh TAS SMA Negeri di Kabupaten Ngawi pada tahun 2018 sebanyak 108 orang, tahun 2019 sebanyak 113 orang, tahun 2020 sebanyak 120 orang, tahun 2021 sebanyak 126 orang, tahun 2022 sebanyak 134 orang, tahun 2023 sebanyak 142 orang, tahun 2024 sebanyak 151 orang, tahun 2025 sebanyak 160 orang, tahun 2026 sebanyak 170 orang, dan tahun 2027 sebanyak 181 orang. Sedangkan untuk SMK Negeri di Kabupaten Ngawi pada tahun 2018 sebanyak 176 orang, tahun 2019 sebanyak 196 orang, tahun 2020 sebanyak 217 orang, tahun 2021 sebanyak 240 orang, tahun 2022 sebanyak 264 orang, tahun 2023 sebanyak 289 orang, tahun 2024 sebanyak 316 orang, tahun 2025 sebanyak 345 orang, tahun 2026 sebanyak 375, tahun 2027 sebanyak 407 orang.

Melihat dari perbandingan TAS yang ada dengan TAS ideal yang harus ada di sekolah sangat tinggi, sehingga peneliti menggunakan analisis kebutuhan TAS moderat. Analisis kebutuhan moderat ini berupaya mencari jalan tengah antara kesenjangan TAS yang ada dengan TAS ideal berdasarkan perkembangan rasio peserta didik, kebutuhan moderat ini dilakukan karena pemerintah tidak mungkin dapat memenuhi kebutuhan ideal TAS yang harus ada di tiap daerah. Berdasarkan analisis yang telah dilakukan peneliti diperoleh data TAS SMA Negeri di kabupaten Ngawi pada tahun 2018 sebanyak 81 orang, tahun 2019 sebanyak 84 orang, tahun 2020 sebanyak 87 orang, tahun 2021 sebanyak 91 orang, tahun 2022 sebanyak 95 orang, tahun 2023 sebanyak 99 orang, tahun 2024 sebanyak 104 orang, tahun 2025 sebanyak 109 orang, tahun 2026 sebanyak 115 orang, tahun 2027 sebanyak 121 orang. Sedangkan TAS SMK Negeri di Kabupaten Ngawi diperoleh pada tahun 2018 sebanyak 143 orang, tahun 2019 sebanyak 157 orang, tahun 2020 sebanyak 173, tahun 2021 sebanyak 190 orang, tahun 2022 sebanyak 208 orang, tahun 2023 sebanyak 228 orang, tahun 2024 sebanyak 249 orang, tahun 2025 sebanyak 272 orang, tahun 2026 sebanyak 301 orang, tahun 2027 sebanyak 320 orang.

Berdasarkan uraian yang terdapat di atas tingkat kebutuhan TAS yang harus dipenuhi diperoleh data kekurangan TAS SMA Negeri di Kabupaten Ngawi pada tahun 2018 sebanyak 26 orang, tahun 2019 sebanyak 29 orang, tahun 2020 sebanyak 32 orang, tahun 2021 sebanyak 36 orang, tahun 2022 sebanyak 40 orang, 2023 sebanyak 43 orang, tahun 2024 sebanyak 47 orang, tahun 2025 sebanyak 51 orang, tahun 2026 sebanyak 56 orang, tahun 2027 sebanyak 61 orang. Sedangkan TAS SMK Negeri di Kabupaten Ngawi pada tahun 2018 sebanyak 34 orang, tahun 2019 sebanyak 38 orang, tahun 2020 sebanyak 44 orang, tahun 2021 sebanyak 49 orang, tahun 2022 sebanyak 55 orang, tahun 2023 sebanyak 
61 orang, tahun 2024 sebanyak 67 orang, tahun 2025 sebanyak 74 orang, tahun 2026 sebanyak 80, tahun 2027 sebanyak 86 orang.

Berdasarkan penelitian proyeksi kebutuhan TAS di SMA dan SMK Negeri Kabupaten Ngawi ditemukan hasil bahwa setiap tahunnya mengalami kenaikan kebutuhan. Selaras dengan hasil penelitian yang dilakukan oleh Parwati (2017) di MTS Negeri Kabupaten Nganjuk, hasil proyeksi kebutuhannya juga mengalami kenaikan pada tahunnya. Faktor kenaikan kebutuhan salah satunya dikarenakan adanya kenaikan jumlah peserta didik yang mengakibatkan kenaikan beban kerja yang harus dijalani oleh setiap pegawai TAS di sekolah. Selain itu faktor lain dari kerbutuhan TAS yang meningkat yaitu pada setiap tahunnya terdapat pengurangan pegawai baik karena habisnya masa kerja (pensiun), perpindahan pegawai (mutasi), kematian, dan alasan lainnya. Hasil yang diperoleh dari analisis proyeksi kebutuhan TAS di SMA dan SMK Negeri Kabupaten Ngawi akan ditempatkan pada tiap-tiap sekolah yang mengalami kekurangan sesuai dengan kebutuhannya.

\section{Persentase Kebutuhan TAS SMA dan SMK Negeri Kabupaten Ngawi}

Proyeksi menurut Poernomo (2016) "memprediksi peristiwa masa depan, dengan pengambilan data historis dan memproyeksikannya ke masa depan, dengan menggunakan beberapa bentuk model matematis". Kemudian peramalan dapat dikatakan sebagai suatu kegiatan penerapan model yang telah dikembangkan pada waktu yang akan datang. Sesuai dengan pendapat diatas dalam hal ini kebutuhan TAS yang ada di SMA dan SMK Negeri di Kabupaten Ngawi dalam analisis data menggunakan beberapa bentuk model matematis, yang nantinya hasil analisis tersebut menggunakan angka persentase kebutuahan yang harus dipenuhi. Persentase kebutuhan yang ada tersebut dapat dijadikan sebagai pengetahuan atau patokan untuk mengetahui kebutuhan TAS SMA dan SMK Negeri di Kabupaten Ngawi dengan mengikuti perkembangan peserta didik di tahun yang akan datang. Selaras dengan pendapat diatas Sumaryono (2014) menjelasakan proyeksi sebagai "sebuah metode yang mampu melakukan analisa terhadap sebuah faktor atau beberapa faktor yang diketahui mempengaruhi terjadinya sebuah peristiwa dengan terdapat waktu tenggang yang panjang antara kebutuhan akan pengetahuan terjadinya sebuah peristiwa di waktu mendatang dengan waktu telah terjadinya peristiwa tersebut dimasa lalu".

Berdasarkan perhitungan proyeksi yang telah dilakukan, persentase kebutuhan TAS SMA Negeri di Kabupaten Ngawi pada tahun 2018 tingkat kebutuahan TAS sebanyak 26 orang atau 32.10\%. Tahun 2019 tingkat kebutuhan TAS sebanyak 29 orang atau 34,52\%. Tahun 2020 tingat kebutuhan TAS sebanyak 32 orang atau 36,78\%. Tahun 2021 tingkat kebutuhan TAS sebanyak 36 orang atau 19,56\%. Tahun 2022 tingkat kebutuhan TAS sebanyak 40 orang atau 42,11\%. Tahun 2023 tingkat kebutuhan TAS sebanyak 43 orang atau 43,43\%. Tahun 2024 tingkat kebutuhan TAS sebanyak 47 orang atau 45,19\%. Tahun 2025 tingkat kebutuhan TAS sebanyak 51 orang atau 46,79\%. Tahun 2026 tingkat kebutuhan TAS sebanyak 56 orang atau 48,70\%. Tahun 2027 tingkat kebutuhan TAS sebanyak 61 orang atau 50,41\%. Persentase kebutuhan TAS SMK Negeri di Kabupaten Ngawi pada tahun 2018 sebanyak 34 orang atau 23,78\%. Tahun 2019 tingkat kebutuhan TAS sebanyak 38 orang atau 24,20\%. Tahun 2020 tingkat kebutuhan TAS sebanyak 44 orang atau 25,43\%. Tahun 2021 tingkat kebutuhan TAS sebanyak 49 orang atau $25,79 \%$. Tahun 2022 tingkat kebutuhan TAS sebanyak 55 orang atau 26,44\%. Tahun 2023 tingkat kebutuhan TAS sebanyak 61 orang atau 26,75\%. Tahun 2024 tingkat kebutuhan TAS sebanyak 67 orang atau 26,91\%. Tahun 2025 tingkat kebutuhan TAS sebanyak 74 orang atau 27,21\%. Tahun 2026 tingkat kebutuhan TAS sebanyak 80 orang atau $27,12 \%$. Tahun 2027 tingkat kebutuhan TAS sebanyak 86 orang atau $26,88 \%$.

\section{KESIMPULAN}

Berdasarkan hasil penelitian dalam pembahasan yang telah diuraikan dapat disimpulkan bahwa: (1) Proyeksi data TAS SMA dan SMK Negeri di Kabupaten Ngawi pada sepuluh tahun terkhir diperoleh data TAS SMA tahun 2018 hingga tahun 2022 sebanyak 55 orang. Tahun 2023 sebanyak 56 orang, tahun 2024 sebanyak 57 orang, tahun 2025 sebanyak 58 orang, tahun 2026 sebanyak 59 orang, dan tahun 2027 sebanyak 60 orang. Sedangkan data TAS SMK Negeri di Kabupaten Ngawi diperoleh tahun 2018 sebanyak 109 orang, tahun 2019 sebanyak 119 orang, tahun 2020 sebanyak 129 orang, tahun 2021 
sebanyak 141 orang, tahun 2022 sebanyak 153 orang, tahun 2023 sebanyak 167 orang, tahun 2024 sebanyak 182 orang, tahun 2025 sebanyak 198 orang, tahun 2026 sebanyak 215 orang, dan tahun 2027 sebanyak 234 orang; (2) Proyeksi data TAS SMA dan SMK Negeri di Kabupaten Ngawi pada sepuluh tahun terkhir ditinjau dari rasio peserta didik. Data TAS SMA Negeri di Kabupaten Ngawi diperoleh Tahun 2018 sebanyak 81 orang dari jumlah tersebut terdapat kekurangan TAS sebanyak 26 orang, tahun 2019 sebanyak 84 orang dari jumlah tersebut terdapat kekurangan TAS sebanyak 29 orang, tahun 2020 sebanyak 87 orang dari jumlah tersebut terdapat kekurangan TAS sebanyak 32 orang, tahun 2021 sebanyak 91 orang dari jumlah tersebut terdapat kekurangan TAS sebanyak 36 orang, tahun 2022 sebanyak 95 orang dari jumlah tersebut terdapat kekurangan TAS sebanyak 40 orang, tahun 2023 sebanyak 99 orang dari jumlah tersebut terdapat kekurangan TAS sebanyak 43 orang, tahun 2024 sebanyak 104 orang dari jumlah tersebut terdapat kekurangan TAS sebanyak 47 orang, tahun 2025 sebanyak 109 orang dari jumlah tersebut terdapat kekurangan TAS sebanyak 51 orang, tahun 2026 sebanyak 115 orang dari jumlah tersebut terdapat kekurangan TAS sebanyak 56 orang, tahun 2027 sebanyak 121 orang dari jumlah tersebut terdapat kekurangan TAS sebanyak 61 orang. Sedangkan data TAS SMK Negeri di Kabupaten Ngawi diperoleh tahun 2018 sebanyak 143 orang dari jumlah tersebut terdapat kekurangan TAS sebanyak 34 orang, tahun 2019 sebanyak 157 orang dari jumlah tersebut terdapat kekurangan TAS sebanyak 38 orang, tahun 2020 sebanyak 173 orang dari jumlah tersebut terdapat kekurangan TAS sebanyak 44 orang, tahun 2021 sebanyak 190 orang dari jumlah tersebut terdapat kekurangan TAS sebanyak 49 orang, tahun 2022 sebanyak 208 orang dari jumlah tersebut terdapat kekurangan TAS sebanyak 55 orang, tahun 2023 sebanyak 228 orang dari jumlah tersebut terdapat kekurangan TAS sebanyak 61 orang, tahun 2024 sebanyak 249 orang dari jumlah tersebut terdapat kekurangan TAS sebanyak 67 orang, tahun 2025 sebanyak 272 orang dari jumlah tersebut terdapat kekurangan TAS sebanyak 74 orang, tahun 2026 sebanyak 295 orang dari jumlah tersebut terdapat kekurangan TAS sebanyak 80 orang, dan tahun 2027 sebanyak 320 orang dari jumlah tersebut terdapat kekurangan TAS sebanyak 86 orang; (3) Persentase kebutuhan TAS SMA Negeri di Kabupaten Ngawi pada tahun 2018 sebesar 32,10\%, tahun 2019 sebesar 34,52\%, tahun 2020 sebesar 36,78\%, tahun 2021 sebesar $39,56 \%$, tahun 2022 sebesar $42,11 \%$, tahun 2023 sebesar $43,43 \%$, tahun 2024 sebesar $45,19 \%$, tahun 2025 sebesar 46,79\%, tahun 2026 sebesar 48,70\%, tahun 2027 sebesar 50,41\%. Sedangkan persentase Kebutuhan TAS SMK Negeri Kabupaten Ngawi pada tahun 2018 sebesar 23,78\%, tahun 2019 sebesar $24,20 \%$, tahun 2020 sebesar $25,43 \%$. Tahun 2021 sebesar $25,79 \%$, tahun 2022 sebesar $26,44 \%$, tahun 2023 sebesar 26,75\%, tahun 2024 sebesar 26,91\%, tahun 2025 sebesar 27,21\%, tahun 2026 sebesar $27,12 \%$, tahun 2027 sebesar $26,88 \%$.

\section{DAFTAR RUJUKAN}

Arikunto, S \& Safruddin. 2006. Prosedur Penelitian: Suatu Pendekatan Praktik. Jakarta: Rineka Cipta.

Hidayat, S. P. \& Nurhikmahyanti, D. 2014. Peran Tenaga Administrasi Sekolah Dalam Meningkatkan Mutu Pelayanan Sekolah Di Man 1 Kota Mojokerto, Jurnal Inspirasi Manajemen Pendidikan, (Online), 4(4):152162. Dari http://ejournal.unesa.ac.id/index.php/inspirasi-manajemen-pendidikan/article/view/7743/10473

Matin. 2013. Perencanaan Pendidikan: Perspektif Proses dan Teknik dalam Penyusunan Rencana Pendidikan. Jakarta: PT Raja Grafido Persada.

Parwati, S. 2017. Analisis Kebutuhan dan Beban Kerja Tenaga Administrasi Madrasah Tsanawiyah Negeri di Kabupaten Nganjuk. Skripsi tidak di terbitkan. Malang: FIP UM.

Priadi, S. 2012. Peran Penting Tenaga Administrasi Sekolah Dalam Penguatan Budaya Sekolah Untuk Implementasi Pendidikan Karakter. Jurnal disajikan dalam Seminar Dewan Pengurus Pusat Ikatan Alumni Universitas Negeri Yogyakarta, 5 Mei 2012. (Online),

Setyadin, B. 2005. Modul I: Dasar-Dasar Penelitian Ilmiah. Malang: Lembaga Penelitian Universitas Negeri Malang.

Sonhadji, A \& Huda, A. Y. M. 2014. Asessmen Kebutuhan Pengambilan Keputusan dan Perencanaan. Malang: Universitas Negeri Malang. 
Sumaryono, R. 2014. Penerapan Metode Trend Moment dalam Forecast Penjualan Beton Readymix di PT. X Mojokerto. Jurnal Media Mahardika. (Online), 13(1)51-57. Dari www.stiemahardhika.ac.id/wp-content/ uploads/2015/05/5.pdf

Syarifuddin. 2011. Meningkatkan Kompetensi Tenaga Administrasi Sekolah (TAS) dalam Mengelola Administrasi Kepegawaian melalui Peran Kepala Sekolah sebagai Manajer, (Online), (https://www.academia.edu) diakses tanggal 02 Desember 2016

Wiyono, B. B. 2007. Metodologi Penelitian (Pendekatan Kuantitatif, Kualitatif, dan Action Research) (Burhannuddin, Ed.). Malang: Fakultas Ilmu Pendidikan Universitas Negeri Malang.

Yuliawati, L. 2014. Perencanan dan Penerimaan Karyawan, (Online), (http://liliekgibranisa.wordpress.com), diakses pada 19 Maret 2017. 